\title{
Linguistic choices for the identity of "China" in the discourse of Czech Sinologists
}

\author{
M elissa Shih-hui L in ${ }^{1}$ (Taiwan)
}

\begin{abstract}
7 his paper utilizes critical discourse analysis (CDA) to disclose the relationship between the lexical or textual device choices of the term "China" in the discourse of Czech Sinologists and how they tried to construct the identity of "China" in interviews collected by Professor Olga Lomovб and her student Anna Zádrapová from 2010 to 2011.

The analysis will focus on how the Czech Sinologists talk about their "China" and evaluate the term "China" in the discourse, within their experiences, and in the context of the social and cultural situation of the time. On the one hand, this paper will discuss the textual devices which convey the term "China" in the interviews of the Czech Sinologists, in the form of linguistic units, such as nouns, adjectives, noun phrases, verbal phrases and so on, and on the other hand, investigate how their identities of "China" are reflected through their choices of lexical or textual devices.
\end{abstract}

Keywords: Critical discourse analysis, Cohesion, Choice, Identity, Czech Sinology

\section{Introduction}

Language plays an important role in the creation and maintenance of social and political ideologies, and ideological positions are reflected through linguistic choices in discourse. (Fowler and Hodge, 1979, 185-283) This paper investigates the process of the ideology, especially the identity formation of "China", through the linguistic choices exhibited in nine interviews with Czech Sinologists.

For the most part, these nine Czech Sinologists started their Sinological studies in the 1950s. At that time, Sinology in Czech was beginning to flourish under the leadership of professor Jaroslav Průšek (1906-1980). Průšek was not the first Czech interested in China. In the $19^{\text {th }}$ century, Rudolf Dvorok (1860-

${ }^{1}$ Department of Slavic languages and literature National Chengchi Univetsity Email: shihhui@nccu.edu.tw 


\section{Linguistic choices for the identity of "China" \\ in the discourse of Czech Sinologists}

1920), professor of Oriental Languages at Charles University in Prague, was the first Czech scholar involved in studies about China. He was a translator of many languages. Chinese was only one of his many interests, and therefore he did not specialize too deeply in the field of Sinology. ${ }^{2}$ Nevertheless his popular works about China did receive the recognition of the general public. However, no one continued his studies. In the beginning of the 1920s, Bohumil Mathesius (18881952) started to do translations of Chinese poetry, but only via third languages. At that time his translations did have some influence on those interested in China. However, true, systematic research about China did not start until after World War II in Czechoslovakia. During the 1950s, Průšek at Charles University in Prague, and later at the Oriental Institute of the Academy of Sciences of the Czech Republic, enabled the rise of the Prague School of Sinology, in which there are some important Sinologists who are still very active now. In 2010 and 2011, Olga Lomová and her student Anna Zádrapová from Charles University in Prague interviewed nine of the first generation Czech Sinologists. This paper aims to deal with these interviews by answering the question, "How did you start to study Sinology?"

This paper will examine the language of the interviewees. The investigation of this intellectual history of China studies will be based on how the mutual constitution of Sinology, Sinologists and their Sinic world has proceeded through individual career paths. (Shih, 2012) It is interesting and also important to discuss what is revealed in the interviews and what the term "China" means to these interviewees. Furthermore, the result might help to reconstruct the "China" image in the Sinology of this post- socialist community.

\section{Background}

In 1937 Průšek returned to Czechoslovakia from China and Japan, and started teaching about China. Even during the Nazi occupation (1939-1945), Průšek continued his teaching in evening classes, which also served as a source of spiritual fulfillment for his followers in the hard war years. In 1947, Průšek was appointed the head of the Department of Far Eastern Studies at Charles University. The teaching staff consisted mainly of students from his wartime courses, including Augustin Palát, Věnceslava Hrdličková and Berta Krebsová, and was regularly supplemented with new graduates, for example Oldřich Král. Here Palot and Hrdličková are also the interviewees in this paper. The other interviewees, including Zlata Černá, Milena Velingerová, Marián Gálik, Zdenka Heřmanová and Josef Kolmaš became Průšek's students after the war and in fact after the Communist takeover in 1948.

2 European Association of Chinese Studies Survey, No.5, (1996): Czech, Hungarian, Slovakian, Slovenian Sinology. 
In April 1949, even before the PRC was established, a Chinese delegation led by Guo Moruo came to Prague. Xu Beihong was also a member of this delegation. Their original destination was Paris, where a peace congress took place, but because they were not given the visas, they stayed in Prague for two or three weeks. Their stay unintentionally encouraged the students who were doing Chinese studies at that time. Afterwards, in the1950s, this first generation of Průšek's followers performed key roles in Chinese studies, especially in the field of modern Chinese literature studies, and were later acknowledged as the "Prague School of Sinology".

According to Lomová and Zádrapová (2012), the basic features of the contribution of the Prague School of Sinology could be summarized as a collection and presentation of rarely studied primary sources, such as modern Chinese literature, field research on popular theatre, storytelling, philosophy of the Han dynasty, always combined with innovative methodological approaches, including structuralism, semiotics, and Marxist theory.

However, in the 1960s, the interaction and cooperation between Czechoslovakia and China, including academic and student exchanges, was interrupted by the changing political environment. In Czechoslovakia, there was Liberalization; at the same time, there was the Cultural Revolution in China. From the middle of the 1970s, some reforms started to be conducted in China, but the Normalization movement began in Czechoslovakia. Consequently, the 1950s was the period when Czechoslovakia and China had the most frequent contact, and it was also the period when the interviewees started their Chinese studies. In 1968, the attack from the Soviet Union army, i.e. the Prague Spring, directly made the relationship between Czechoslovakia and China worse and brought negative influence on Sinological studies in Czechoslovakia. In the following 20 years, Czech Sinology was further isolated from the world. During that period, most of the Sinologists were forced to give up their jobs, and some of them stopped research in what they were interested. For example, Heřmanov6 was forced to make reports about China to the government at that time, and had to translate Chinese daily newspapers and the Constitution of the People's Republic of China, which were irrelevant to Chinese literature, her true interest. However, the Sinologists of that time still tried their best to continue their research interests privately. For example, Heřmanovб and Danuška Heroldovб completed nine volumes of Czech-Chinese dictionaries on very limited budgets between 1974 and 1984.

After the Velvet Revolution in 1989, the social and political system in Czech was changed. At the same time, China was rising. The interaction between Czech and China became more and more active, and drove the prosperity of Sinology in Czech. Although the interviewees in this paper, having graduated in the 1950s, were growing old and in some cases even passing away, their influence on Czech 


\section{Linguistic choices for the identity of "China" \\ in the discourse of Czech Sinologists}

Sinology was still very strong. According to the interviews, some interviewees believe the intention of Průšek was to establish all the basic disciplines forming the Sinology via each of his students. That means Průšek chose the students according to the need of the disciplines. Although not all of the interviewees agree with this assumption, nowadays Průšek's students do take responsibility for different areas of Chinese culture and work on it together. Current Czech Sinological studies do look like a systematic network created by Průšek's students and his followers.

In this paper, there are nine interviews with these Sinologists, collected by Olga Lomov6 and her student Anna Zádrapová from 2010 to 2011. In these interviews, these Sinologists tried to answer the question - How did you start to study Sinology? Through the answers the term "China" was interpreted in many different ways. The way the lexical or textual device was presented is the main concern of this paper. To investigate the "China" in the mind of these Sinologists brings some new insights about the Prague School of Sinology.

\section{Methodology}

This paper is based on interviews with nine Czech Sinologists who started their Chinese studies during the 1950s. The interviews were conducted by the current Czech Sinologists. Since the materials analyzed in this paper are not collected by the author, it would be better to look at the interviews as a whole. The author believes there is always evidence that the interviewer and interviewees are involved in somewhat different social activities in their respective interviews. The interviewer and interviewee share a good deal of situated meanings and cultural models. Their interview is akin to a collaborative discussion, in which they readily enact their mutual affiliation in their language. (Gee, 1999)

An interview is one form of a larger meaningful unit for discourse analysis, which deals with how the choice of articles, pronouns, and tenses affects the structure of the discourse, the relationship between utterances in a discourse, and the moves made by speakers to introduce a new topic, change the topic, or assert a higher role relationship to the other participants. (Halliday and Ruqaiya, 1985) Some analysts think discourse analysis is an interpretive activity because its purpose is to help the message receivers understand the meaning of the text and the message producers. However, in this paper first the author will follow the argument derived from the functional discourse analysis of Halliday and Hasan (1976): the purpose of the discourse analysis is explanation not interpretation; its purpose is to explain why the discourse expresses the meaning. In other words, the purpose of "interpretation" is to understand what the meaning of the discourse is, but the purpose of "explanation" is to make clear how the discourse expresses 
its meaning. That is to say that the purpose of functional discourse analysis is to evaluate the discourse. Before evaluating, discourse analysis must study the discourse from "what is the meaning of the discourse?", "how does the discourse express the meaning?", "why does the discourse express the meaning?" and so on. In all, the purpose of functional discourse analysis is explanatory activity to evaluate the discourse.

Second, the author will look at the discourse materials within the scope of critical discourse analysis. The goal of the analysis in this paper is not only to explain and evaluate the discourse in the interviews, but also to focus on the relationship between some specific language units and the ideology formation process. Discourse is the reproduction of existing social relations and structure, and aspects of texts are of ideological significance. (Hodge and Kress, 1993) In the past decades, critical linguistics and critical discourse analysis have made a significant contribution to illuminating the relationship between language and ideology in discourse. (Fairclough, 1995; Fowler, 1991; Van Dijk, 1988, 1991) In critical discourse analysis, Fairclough followed systematic linguistics (Halliday, 1978) in assuming that language in text always simultaneously functions ideationally in the representation of experience and the world, interpersonally in constituting social interaction between participants in discourse, and textually in tying parts of a text together into a coherent whole and tying texts to situational contexts. (Fairclough, 1995) In this paper, critical discourse analysis will focus on how the Sinologists talk about and evaluate "China", to disclose the relationship between the lexical or textual devices choice of the term "China" in the discourse of these Czech Sinologists and how they try to construct the ideology of "China" in their discourse.

On the one hand, the discourse about "China" can connect intimate details of the personal experience to broader social relations, and on the other hand, examining what these Sinologists have to say about their personal experience provides useful insights into social processes and events. The larger social context of what people say is also important for analysis and the social discourse and politics that frame discourse must be included in any interpretation of ideological construction. (Wiles, Rosenberg, and Kearns, 2005)

\section{Analysis and Discussion}

According to Shih (2012), an analysis of choice is important because it may reconstitute our knowledge to incorporate both scientific and judgmental components. Moreover, it may tell an emotionally embedded history of knowledge. In this paper, the linguistic choices of the term "China" in the discourse of these Czech Sinologists reveal their ideas about "China", and it is 


\section{Linguistic choices for the identity of "China" in the discourse of Czech Sinologists}

assumed that the analysis of these linguistic choices might help reconstitute the knowledge about "China". In the following, the author will try to investigate these linguistic choices.

Before the investigation, the author has to mention the way in which to find the linguistic choices of the term "China". It is based on "cohesion". Cohesion is the grammatical and lexical link within a text or sentence that holds a text together and gives it meaning. (Halliday, 1976) Linguistically, there are two main types of cohesion: grammatical, referring to the structural content, and lexical, referring to the language content of the piece. Due to the grammatical or lexical cohesion, the choice of words for one specific term could be interpreted as a whole. It provides cues for interpreting events or experiences. That is to say, lexical items not only construct particular ideological representations of experiences or events, but also have expressive value implying the producer's positive or negative evaluation of actions, participants, and events. (Kuo, 2001)

According to the lexical or grammatical cohesion, the author would like to illustrate some examples of how the interviewed Czech Sinologists chose terms when they mentioned China. The choices of linguistic forms in the interviews reflect the ideological position of "their China". Some linguistic devices are employed to emphasize the truth value of the positive attitude, and at the same time to express the negative evaluation. The analysis of this paper will focus on nouns, noun phrases and verbal phrases / clauses.

\section{Nouns and noun phrases}

(1) China was a last thing to me. ${ }^{3}$

(2) /China is/ a country with the great future. ${ }^{4}$

(3) when we read Mathesius, we asked ourselves: what is this Chinese language like, such a beautiful poetry. ${ }^{5}$

(4) what would I do with the Chinese... I said I wanted to do something special. ${ }^{6}$

In the examples (1), (2), (3) and (4), the noun phrases "a last thing to me", "a country with the great future", "such a beautiful poetry", and "something special" all reveal the positive expression to the term "China". These linguistic items not only construct particular ideological representations of experiences or events but also have expressive value implying the producer's positive evaluation. In example (1), Gálik was recalling the memory when he had just begun to study

\footnotetext{
Gálik, Marián. 2011. Interviewed by Olga Lomová and Anna Zádrapová.

Hrdličková, Věnceslava. 2010. Interviewed by Olga Lomová and Anna Zádrapová.

Hrdličková, Věnceslava. 2010. Interviewed by Olga Lomová and Anna Zádrapová.

Velingerová, Milena. 2010. Interviewed by Olga Lomová and Anna Zádrapová.
} 
Chinese, and in examples (2) and (3), Hrdličková mentioned about her and her husband's first impression of China. In example (4) Velingerová tried to describe her preliminary intention to study Chinese.

There is another example which conveys quite positive evaluation of "China". In example (5), Heřmanová explained her motivation for Chinese translation:

\section{(5) People seemed to be hungry for the exotic things, China was admired. ${ }^{7}$}

In example (5), the connotation of the noun phrase "the exotic things" is not easily defined as absolutely positive or negative, however thanks to the term "admired" used immediately after it, "the exotic things" definitely conveys positive evaluation. There is another example in (6):

(6) As I said, Chinese studies were the matter of enthusiasts, at that time, they were eager to know China, country so different. ${ }^{8}$

In example (6), Palát was describing the situation of Chinese studies in the sixties. He pointed out the lack of attention to Chinese studies at that time. For example, when people were interested to study Roman languages, they learned languages in high school, knew history, culture, literature. Even had they wanted to they could not have avoided exposure to Roman languages and culture. This applied especially when it came to Austria, Germany and England. But at this time there was only one page devoted to China in high-school textbooks. So, in the example (6), Palát emphasized that China studies were "the matter of enthusiasts", who were eager to know such "country so different". The evaluation of these noun phrases about the term "China" is quite positive. Only such positive motivation could bring the people to devote themselves to such a "different" subject.

There are also examples showing neutral evaluation with unclear expression. In example (6), Slupski expressed his opinion about teaching Sinology:

(7) Palát told me Sinology ought to continue in Prüšek's way: history, philosophy and literature - those main subjects. My personal opinion is slightly different: I would add the comparative aspect to both Sinology and its teaching. People found out China was original, peculiar civilisation. But if you inform someone about the Chinese culture, you need the comparative background to make the differences obvious. People can't discover it, people don't care, they don't think about it. Student should be directed

Heřmanová, Zdenka. 2010. Interviewed by Olga Lomová and Anna Zádrapová.

8 Palát, Augustin. 2010. Interviewed by Olga Lomová and Anna Zádrapová. 


\section{Linguistic choices for the identity of "China"}

in the discourse of Czech Sinologists

to see and look for the differences. ${ }^{9}$

In example (7), although the connotation of the term "peculiar" should be more negative, it becomes neutral because of the adjective "original". In this example, the evaluation of "China" is quite neutral with somewhat unclear expression.

There are also examples which show some negative evaluation about "China" in the interviews, For example, when Dřínek mentioned his impression on China in example (8).

(8) many contradictions, backwardness, but the educated intelligence on the other hand. ${ }^{10}$

In example (8), the nouns with negative expressions "contradictions" and "backwardness" are used, and at the same time with the appearance of the positive expression "the educated intelligence", which in the end expresses quite neutral connotation, but with some contradiction, as he himself mentioned in this example. This "contradiction" appears also in other following examples, so it shall be discussed in the following.

\section{Verbal phrases / clauses}

There are also some verbal phrases / clauses used to describe the term "China" in these nine interviews. In example (9), Velingerov6 was asked about her first impression of China and her later impression when she really involved herself in her studies.

(9) My first era was under the influence of professor Průšek - My Sister China. China was an idealized country for me, absolutely fantastic country where I must go and so on. The second phase came after I saw China-I found out it wasn't so simple. ${ }^{\text {II }}$

In the example above, Velingerová first used "an idealized country for me, absolutely fantastic country where I must go" to describe her first impression of China, but later she proposed her puzzlement noting her uncertainty about her first impression: "I found out it wasn't so simple" when she really saw China. Although there is no such "contradiction" in this example when Velingerová tried to describe her "China", there is hesitancy and lack of clarity in her later impression.

9 Slupski, Zbygniew. (2011) Interviewed by Olga Lomová and Anna Zádrapová.

10 Dřínek, Vladislav. (2011) Interviewed by Olga Lomová and Anna Zádrapová.

11 Velingerová, Milena. 2010. Interviewed by Olga Lomová and Anna Zádrapová. 
In examples (10) and (11), another interviewee G6lik also mentioned about his first and later impression of China, and his attitude went from negative to positive. In example (10), Gálik was asked about his strongest impression of China by the interviewer, and he replied to this question referencing his first arrival in China at Beijing airport in the late fifties.

(10) When I was at the aircraft above Beijing, there were corn and sorghum fields all around, quite a difference from today's state, and after I entered the university, I was surprised nothing was prepared although they were informed of our arrival.... I was surprised by the tiny airport. The only lonely bell boy was there who was sitting somewhere in the corner behind, I saw two three buildings and it was all. I didn't get anything to eat the first day, well, I had some snack later. But when I walked out from the university gate, there was nothing but an open space. Today the area between Beijing University and Qinghua University is all built-up. The only thing I could see there were the small Chinese's naked posteriors. I was also surprised by their buggies. The weather was nice at that time, but later I found out they are naked in winter, too, I couldn't understand it. ${ }^{12}$

What Gálik described upon his first arrival to China was not very positive: "nothing was prepared although they were informed of our arrival", "I didn't get anything to eat the first day" and so on. In example (11), G6lik continued to describe the different images of "China" in his mind when he was eleven and sixteen.

(11) I saw in my eleven: the picture represented the opium smokers. The picture was so terrible I can see it even now in my head. I read various things in the books: Chinese are stingy and arrogant, they offer something and they expect you to refuse it. So my image of China wasn't very nice at all. I can recall Tiananmen very well, how old was I in 1949. It was very interesting for me, it was quite a different change! However, I had a catholic education, Mao Zedong was not my idol, but when I got the chance to study Chinese and when I saw the perspective is good in this subject, I took it. ${ }^{13}$

In example (11), when Gálik was eleven, he used "the picture represented the opium smokers. The picture was so terrible" and "Chinese are stingy and arrogant, they offer something and they expect you to refuse it" to express his first impression of China, which was full of negative connotation. When he was

${ }^{12}$ Gálik, Marián. 2011. Interviewed by Olga Lomová and Anna Zádrapová.

13 Gálik, Marián. 2011. Interviewed by Olga Lomová and Anna Zádrapová. 


\section{Linguistic choices for the identity of "China" \\ in the discourse of Czech Sinologists}

sixteen, which means when he first started to get in touch with Chinese studies, he used "It was very interesting for me, it was quite a different change" to describe the positive change of the Chinese image in his mind. At the same time, he emphasized that he did not agree all about China: he mentioned that "However, I had a catholic education, Mao Zedong was not my idol", but why he still took the chance to study Chinese was because of a process of rational consideration: "when I got the chance to study Chinese and when I saw the perspective is good in this subject, I took it". From examples (10) and (11), it seems that Gálik's first impression of China was quite negative, but later he held a rather positive attitude toward his "China".

Another interviewee, Kolmaš, who studied not only Chinese but also Tibetan in the 1950s, used example (12) to describe his impression of China.

\section{(12) China was THAT country, you know. ${ }^{14}$}

In example (12), "THAT" was used as an intensive word and "you know" can be treated as a discourse marker to emphasize the truth of the preceding clause. Kolmaš mentioned this clause when he was talking about his translation work. In the interview with him, he did not use any concrete lexical items to describe the term China, neither did Švarný. Example (12) only reveals Kolmaš's complicated feelings toward China, and the evaluation was very unclear.

The following example (13) explains the reason why the unclear evaluation of "China" appeared in several interviews.

(13) The situation of the sixties was very special, you know. The political pressure existed towards negative informing about China, but on the other hand, the Sinologists'attitude towards Chinese events was negative, too. Our political postures agreed with the postures of the political forces. $\underline{B u t}$ even so, nobody wanted to write negative things about China, although everybody knew there was nothing positive to say about the Chinese revolution... people held back, they didn't want to barge in on it. ${ }^{15}$

In example (13), Slupski tried to describe the contradiction in the sixties. He pointed out that although "the Sinologists' attitude towards Chinese events was negative", "nobody wanted to write negative things about China". His conclusion was "people held back, they didn't want to barge in on it." He also mentioned that the main reason was "the political pressure". It can be assumed that the other uncertain or unclear evaluations of the term "China" found in other extracts are also caused by the political background of the time. The change of the evaluation

${ }^{14}$ Kolmaš, Josef. 2011. Interviewed by Olga Lomová and Anna Zádrapová.

15 Slupski, Zbygniew. 2011. Interviewed by Olga Lomová and Anna Zádrapová. 
might also reflect the change of the political scenes simultaneously. In the following paragraph, the author will use a table to explain more clearly these assumptions.

Here the author tries to rearrange the examples mentioned above in the following table by putting the nine interviewees' names in the table, although the author did not find any extracts which were used to describe the term "China" in the interview with Švarnэ. In this table, "P" means positive, "N" is negative and "?" indicates unclear evaluation or contradiction. There are also " $\mathrm{P} \rightarrow$ ?" and "N $\rightarrow \mathrm{P}$ " in the table. The former means the evaluation changes from positive to unclear or neutral; the latter indicates a negative evaluation changes to positive. However, the author would like to emphasize here that the evaluation is based on the extracts of the nine interviews, not targeted at any particular individuals.

\begin{tabular}{|c|c|c|c|c|c|c|c|c|c|}
\hline interviewees & & & & & & & & & \\
\hline examples & Gálik & Hrdličková & Velingerová & Heřmanová & Palát & Slupski & Dřínek & Kolmaš & Švarný \\
\hline$(1)$ & $\mathbf{P}$ & & & & & & & & \\
\hline (2) & & $\mathbf{P}$ & & & & & & & \\
\hline (3) & & $\mathbf{P}$ & & & & & & & \\
\hline (4) & & & $\mathbf{P}$ & & & & & & \\
\hline$(5)$ & & & & $\mathbf{P}$ & & & & & \\
\hline (6) & & & & & $\mathbf{P}$ & & & & \\
\hline (7) & & & & & & ? & & & \\
\hline$(8)$ & & & & & & & $?$ & & \\
\hline$(9)$ & & & $\mathbf{P} \rightarrow$ ? & & & & & & \\
\hline$(10)$ & $\mathbf{N}$ & & & & & & & & \\
\hline$(11)$ & $\mathbf{N} \rightarrow \mathbf{P}$ & & & & & & & & \\
\hline (12) & & & & & & & & ? & \\
\hline (13) & & & & & & ? & & & \\
\hline
\end{tabular}

From the table above, Hrdličková, Palát and Heřmanová chose the linguistic items to show their positive evaluation of the term "China". In the interviews with Gálik and Velingerová, the evaluation of the term "China" changes over time. Slupski, Dř́nek and Kolmaš chose linguistic items to convey unclear evaluation layered with contradiction. In the first group, Hrdličková and Palát were Průšek's wartime course students in the 1940s, and they started their Chinese studies much earlier than the others; Heřmanová became Průšek's student after the war, i.e. after the Communist takeover in 1948, as with the rest of the interviewees. She went to China from 1953 to 1958, which was earlier than the others. So, it seems, according to the nine interviews, the Sinologists who had contact with Chinese studies earlier expressed more positive evaluation of the term "China". This might also be caused by the influence of the communist regime of the time. 


\section{Linguistic choices for the identity of "China" \\ in the discourse of Czech Sinologists}

The more influence the interviewees received from the communist regime, the more unclear the evaluation and the more contradiction showed in their linguistic choices for the term "China".

There is one more thing which needs to be mentioned: in these nine interviews, the interviewees repeatedly mentioned the name Jaroslav Prǔšek. Palбt mentioned it 97 times, Gálik mentioned it 77 times, Kolmaš 59 times, Slupski 47 times, Velingerová 43 times, Hrdličková 31 times, Švarný 13 times and Heřmanová 11 times. It might explain the importance of Průšek in their Sinological career paths. As Lomová and Zádrapová mentioned in 2012, "all acknowledged that Průšek's publication and personal example were a decisive factor for them to study Chinese language and Sinology".

\section{Conclusion}

This paper has investigated how ideological positions of "China" are reflected through the choices of lexical or text devices by the Czech Sinologists who mostly graduated in the 1950s. The discussion provides cues for interpreting events or experiences during the period when the Prague School of Sinology began to rise.

According to the analysis and discussion in this paper, some linguistic devices about the term "China" are employed to emphasize the truth-value of the positive attitude, and some are employed to demonstrate unclear evaluation and even contradiction. It can be concluded that the different evaluations were dependent on when the interviewees began contact with Chinese studies. At the same time the evaluations were most definitely influenced by the political climate of the time. However, the analysis in this paper is still not complete. More in depth interviews and more relevant reference materials are needed to support these conclusions.

\section{References}

Dijk, T.A. van. 1988. News as Discourse. Hillside, NJ: Erlbaum.

Dijk, T.A. van. 1991. Racism and the Press. London: Routledge.

European Association of Chinese Studies Survey no.5, 1996: Czech, Hungarian, Slovakian, Slovenian Sinology.

Fairclough, Norman. 1995. Critical Discourse Analysis: The Critical Study of Language. Longman.

Fowler, R. 1991. Language in the news: Discourse and ideology in the press. London: Routledge.

Fowler, R. and B. Hodge (1979). Critical linguistics. In R. Fowler et al (Eds.).

Language and Control. London: Routledge and Keegan Paul. pp. 185-213 
Fürst, R. 2010. Česko-čínské vztahy po roce 1989 (The relation between Czech and China after 1989). Praha: Karolinum.

Gee, James Paul. 1999. An Introduction to Discouse Analysis: Theory and Method. London, New York: Routledge.

Grace, George W. 1987. The Linguistic Construction of Reality. New York: Croom Helm.

Halliday, M.A.K. 1978. Language as social semiotic: The Social Interpretation of Language and Meaning. University Park Press.

Halliday, M.A.K. \& Ruqayia Hasan 1976. Cohesion in English. London: Longman.

Halliday, M.A.K. \& Ruqaiya Hasan. 1985. Language, context and text: a social semiotic perspective. Geelong, Vic.: Deakin University Press.

Kuo, Sai-hua. 2001. 'Is there only one China?': Analyzing the rhetoric of Chinese nationalism in a newspaper article. Journal of Asian Pacific Communication.

Lomová, Olga and Anna Zádrapová. 2012."The Songs of Ancient China” myth of "The Other" appropriated by an emerging Sinology. Paper presented at International Conference on New Perspectives in East Asian Studies. Taipei, Taiwan.

Mádlová, V. 2011. Jaroslav Průšek (1906-1980): prameny k životu a dílu zakladatele pražské Sinologické školy (Jaroslav Průšek (1906-1980): sources on the life and work of the founder of the Prague School of Sinology). Praha: Masarykův ústav a Archiv AV ČR.

Salkie, Raphael. 1995. Text and Discourse Analysis. London, New York: Routledge.

Schiffrin, Deborah, Deborah Tannen and Heidi E. Hamilton. 2003. The Handbook of Discourse Analysis. Blackwell.

Shih, Chih-yu, "Comparative Intellectual History of Chinese Studies: Micro Identity and Macro Civilizaiton," Asian Research Trend New Series 7 (Tokyo, 2012).

Šíma, J. 1994. Jaroslav Průšek: Bibliografie 1931-1991. Praha: Akademie věd České republiky, Orientální ústav.

Wiles, Janine L., Rosenberg, Mark W., and Kearns, Robin A. 2005. "Narrative Analysis as a Strategy for Understanding Interview Talk". Area 37(1); 89-99.

Norman Fairclough, Critical Discourse Analysis: The Critical Study of Language (London: Longman, 1995). Fowler, R. (1991). Language in the news: Discourse and ideology in the press. London: Routledge. ; 